\title{
Entrepreneurship, Innovation and Public Policy: A Survey of Literatures
}

\section{Quttainah MA*}

College of Business Administration, Kuwait University Safat, Kuwait

\begin{abstract}
This paper intends to explain the relationship between innovation and entrepreneurship as crucial determinants of economic growth. Individual differences are what scholars in the emerging field of entrepreneurship view as relevant, usually undermined factors that account for the success of entrepreneurs. Policymakers usually initiate public policies from what economists have to say. It is not surprising policymaking process originates as top down approach. This paper tries to accomplish two tasks. "In informal attempts to explain [the growth of free market economy], the terms 'innovation' and 'entrepreneur' frequently recur. Yet in the main body of our writings on microeconomic theory these two words are also scarcely to be found".
\end{abstract}

Keywords: Entrepreneurship; Innovation; Market economy

\section{Introduction}

As the world economy is moving towards entrepreneurial, knowledge-based, Innovation is perceived as the critical source of competitive advantage [1] and is one of the most important factors responsible for economic growth [2]. This paper will attempt to bridge the literatures that [3] Baumol argues are "scarcely to be found". Specifically, we will survey the related works on economics of innovation and entrepreneurship. Beyond that, one specific issue relating innovation with entrepreneurship is to be considered in details. In particular, this paper will focus on the emergence of "entrepreneurial policy" as the result of the shifts of public sentiment towards the revitalization of innovation and entrepreneurship.

Neoclassical economics traditionally considers innovation and entrepreneurship as residuals in economic growth equations. Only later that innovation was put into equations, with the development of endogenous growth models [4-6]. The basic premises of these models are that knowledge impact growth endogenously and that there are increasing returns in the production of goods with respect to technology change. Therefore, innovation can shift economy from its steady state to new long run equilibrium. But, even until recently, only innovation is accounted explicitly in standard economic growth models. Entrepreneurship, on the other hand, is still missing from the equations. There are few attempts that try to find the missing links among innovation, entrepreneurship and economic growth. Michelacci [7] argues that technological change requires both researchers who create inventions and entrepreneur who transform those inventions into innovations. Acs et al. [8] argues for the differences between knowledge and economically relevant knowledge. They extend endogenous growth model to include "filter between knowledge and economic knowledge" and argue that entrepreneurship is "the mechanism that reduces the knowledge filter".

However, as economists have begun to regard both innovation and entrepreneurship as the crucial determinants of economic growth, they still cannot find the way to account for individual differences. Individual differences are what scholars in the emerging field of entrepreneurship view as relevant, usually undermined factors that account for the success of entrepreneurs [9]. Policymakers usually initiate public policies from what economists have to say. It is not surprising policymaking process originates as top down approach. In contrast, it is urged that to understand entrepreneurial process, we need to consider building theory from bottom-up [10].

Therefore, it is relevant to pull together the literatures on innovation, entrepreneurship, and public policy to understand their shared ideas and differences develop an integrative framework, as well as identify important research questions. Next three sections, we will review relevant works on theory of innovation, theory of entrepreneurship, and that attempts to integrate both theories. Then, we will discuss about entrepreneurial policy, covering "what it is" and "why we need it". The last section we will discuss the implication of this paper and propose future directions of research.

\section{Theory of innovation}

In the recent decades, we have seen the unprecedented growing amount of literatures on innovation. Despite a large number of empirical works, theoretical breakthroughs are rare, especially at the micro-level.

Why the literature is still so thin in scope? One explanation is that rational choice theory is still, to a large extent, a dominant paradigm. Most empirical works based their studies on "the knowledge production function". Even though this improved theory has replaced "the standard production functions, it is still based on mathematical optimization, requiring the strong assumption that individuals are selfutility-maximizers.

The knowledge production function paradigm began when economists started to realize that productivity growth cannot simply be explained by the increases of two common economic inputs, capital and labor. In contrast, technology plays a crucial role [11]. Arrow [12] observes that such discovery does not contradict to the neoclassical view of production function. He argues, "all that has to be added is the obvious fact that knowledge is growing in time". Arrow [12] models technological change endogenously within the production function in terms of "experience" or "learning by doing." In a later study, Cohen and Levinthal [13] propose that technological change generates two distinct effects on productivity. On one hand, innovation directly increases the rate of output. On the other hand, innovation, perceived as "learning process" enhances "firms' capabilities to assimilate and exploit externally available information". These dual roles imply that innovation can be conceived in terms of opportunity creation, as innovation output generate new opportunities, and opportunity

*Corresponding author: Majdi Anwar Quttainah, College of Business Administration, Kuwait University, Safat, Kuwait, Tel: 24983333, Ext-88556; E-mail: mquttainah@cba.edu.kw

Received July 17, 2015; Accepted July 30, 2015; Published August 04, 2015

Citation: Quttainah MA (2015) Entrepreneurship, Innovation and Public Policy: A Survey of Literatures. Int J Econ Manag Sci 4: 279. doi:10.4172/21626359.1000279

Copyright: ( 2015 Quttainah MA. This is an open-access article distributed under the terms of the Creative Commons Attribution License, which permits unrestricted use, distribution, and reproduction in any medium, provided the original author and source are credited. 
discovery, as innovation process enhances firms' ability to exploit opportunity that available externally.

The main contribution from the knowledge production function is that it helps overcome the measurement difficulties inherent in an encompassing definition of technological change. Most studies attempt to assess the contribution of $\mathrm{R} \& \mathrm{D}$ (as innovation input) to productivity growth. Building the core concept for this research paradigm is Griliches [14,15], who introduced the extended CobbDouglas production function as a basic micro-econometric framework for measuring the impact of R\&D on firm growth. In his model, the focus is on total output or total factor productivity as a function of past R\&D investments. Therefore, the estimated coefficient associated with $R \& D$ investment can be perceived as the elasticity of $R \& D$ on output or the rate of return to R\&D. Various studies have applied the $\mathrm{R} \& \mathrm{D}$-augmented Cobb-Douglas production function in either crosssectional or time-series dimensions. However, Acs and Audretsch [16] find that such studies provide good analytics for aggregated level, but they are less compelling when studied at micro level. Furthermore these studies only tell us the extent to which opportunities are created endogenously [16]. In contrast, Cohen and Levinthal's thesis already imply that innovation both create opportunities and enhance firms' ability to recognize opportunity [13]. In addition, a more interesting question that "how opportunities are created and discovered" never been properly answered, as long as the most important construct that create and discover opportunities - the entrepreneur - are ignored from the studying model.

\section{Theory of entrepreneurship}

Although Schumpeter is one of the most influential contributors to innovation literatures, what lying at the heart of his contributions is the theory of the entrepreneur [17]. Schumpeter introduce the role of the entrepreneur in a chapter called the Fundamental Phenomenon of Economic Development in his seminal work [17], as he stated that, "Development is the carrying out of new combinations. This concept covers the following five cases: (1) The introduction of a new good-that is one with which consumers are not yet familiar-or of new quality of a good. (2) the introduction of new method of production, that is one not yet tested by experience in the branch of manufacture concerned, which need by no means be founded upon a discovery scientifically new, and can also exist in a new way of handling a commodity commercially. (3) The opening of a new market that is a market into which a particular branch of manufacture of the country in question has not previously entered, whether or not this market has existed before. (4) the conquest of a new source of supply of raw materials or half-manufactured goods, again irrespective of whether this source already exists or whether it has first to be created (5) The carrying out of the new organization of any industry, like the creation of a monopoly position (for example through trustification) or the breaking up of a monopoly position [18].

He added that "These combination are, as a rule, embodied, as it were, in new firms which generally do not arise out of the old ones but start producing beside them" [18].

According to Schumpeter [17], entrepreneur act very much like an innovator. In Schumpeterian tradition, economy is constantly in its disequilibrium due to wave of "creative destruction" created by innovative entrepreneur.

After Schumpeter [17], there seems to be the losing decades in which mainstream economists ignored the role of entrepreneurs. (Even Schumpeter himself, in his later seminal work in 1942, shifted his focus from "individual entrepreneur/innovator to large firm's innovator) Only the last two decades that we have witnessed the emergence of new field of economic analysis that again takes the role individual entrepreneur into account. These include the new institution economics and behavioral economics [19]. Such emerging fields share at least five principles, which are the followings [19].

a) Individuals are assumed to be bounded rational. In other words, individuals entail limited cognitive abilities that constrained their problem solving and thinking process.

b) Individuals are modeled as rule followers. Their actions are shaped largely by rules.

c) Institutions matter significantly. Institutions influence the course of actions undertaken by individuals.

d) With the assumption of bounded rationality, the linkage between economics and cognitive psychology is needed to take into consideration.

e) Economic phenomena are often evolutionary. Because economic outcomes are constrained by interactions and interdependencies among individuals and institutions, sub-optimality outcome can emerge from time to time.

Arguably, this five principles bridge the study of economics with other disciplines - including the new entrepreneurship [19].

Behavioral economics studies the economic consequences when individual do not always behave rationally. Although optimization and equilibrium concept is still used in behavioral economics, rational choice assumption is not assumed [20]. The core assumption of behavioral economics posits that individual's decisions are subjected heuristics and biases. These heuristics and biases are common characters of the entrepreneur, who usually acts on complex opportunistic situation without complete knowledge [21,22].

New institutional economics focus on the role of institution in shaping economic behavior. This implies that, while entrepreneur represents in all institutional settings, it is the differences in institutional contexts that lead to different growth opportunities across societies [23] New institution economics [19], drawing its notion mainly from the Austrian school [24], views entrepreneurship as "equilibrating force" and as "the catalyst of economic growth". When institutional changes occur, entrepreneur act on "profit opportunity" so that entrepreneur is "the mean" or "the mechanism" toward "the end" - the growth of the economy.

Comparing with the neoclassic [19], this new fields of economics provide rich concepts for integrating with the recent development in theory of entrepreneurship in other disciplines. Next section we will discuss how economic theories of innovation and entrepreneurship can be integrated to provide a more useful framework for analysis.

\section{Towards integrative theory}

Why great firms, even ones consistently invest in $R \& D$, fall? Why small, new firms can disrupt the market and ultimately replace much larger incumbents? These questions are not new but yet there is no good answer available. Schumpeter, Christensen $[25,26]$ have tried to explain this phenomenon. We know that innovation itself does not explain the whole story without considering the entrepreneur. But how can we integrate theories of innovation and entrepreneurship in order to explain such phenomenon soundly? We believe that we need to start from the very beginning - how we define entrepreneurship. 
Shane and Venkataraman's entrepreneurship seems to encompass all important aspects of the study of entrepreneurship that we need to address. They argue that entrepreneurship involves "the study of the sources of opportunities; the processes of discovery, evaluation, and exploitation of opportunities; and the set of individuals who discover, evaluate, and exploit them" [2]. According to this description, the study of entrepreneurship, to a large extent, already addresses the same set of questions we need to consider for the study of innovations. All we think is important to add to this description is entrepreneurship should not only address the process of opportunity discovery but also take into account the process of opportunity creation. Both opportunity discovery and opportunity creation are equally important aspects of entrepreneurial process and should be considered simultaneously.

Based on Burgelman and Hitt [27], we develop a simple model of entrepreneurial process, but with the addition of feedback loop for opportunity creation. Figure 1 show that opportunity can be either discovered externally, through the recognition of new market information, or created internally, through the introduction of innovations.

Fortunately, it is obvious that entrepreneurship has been studied extensively when economists investigate issues of innovation Miniti and Levesque [19], while innovation is also addressed explicitly in the field of entrepreneurship (For instance, the first issue of the new Strategic Entrepreneurship Journal have sections on innovation and entrepreneurship). We have heard new terminologies such as "innovative entrepreneurship" and "strategic entrepreneurship" more and more frequently. For the theoretical development of these new topics, researchers have no alternatives but to adopt both multidisciplinary and multilevel perspectives.

\section{The role of public policy}

"Productive entrepreneurship in the free market economies, then, has been encouraged materially by contraction of the opportunities for financial gain through rent seeking and destructive activities, and by the simultaneously explosion of ways of wealth-gathering in productive occupations. Productive entrepreneurship has also be stimulated by the growing power of rules of law and concomitant upon arbitrary exercise of government power" [1].

As the above statement points out, it is argued that government intervention should have effects on entrepreneurship. Particularly, government intervention can stimulate the level of entrepreneurial activity in the economy. But, for any free market, the implementation of public policies and other public interventions need to be justified. What are reasons behind government interventions? Economists justify such interventions in the presence of market failures. Market failures mean that the market mechanism fails to operate efficiently so that the social benefit is less than optimal. There are several reasons for market failures that associated innovation and entrepreneurship, including market structure and firm size, capital market imperfections, uncertainty and information asymmetries, institutions and regulation, and externalities $[3,28,29]$.

Various arguments have been purposed to justify the positive relationship between firm size and entrepreneurial action/innovation $[30,31]$. Firstly, there is scale economies associated with entrepreneurial action/innovation, and the fixed costs of such action are high. Lastly, large firms can benefit from synergies (scope economies) between investing in new entrepreneurial/innovation projects and conducting their various manufacturing activities. Lastly, because small firms have relatively limited number of strategic resources, they bear higher risk than large firms in terms of information leakage.

Capital market imperfection is another source of market failure. Only large firm has the advantage in financing their entrepreneurial projects internally. Furthermore, small firms seek for external funding usually find difficulties. This is because lenders are often very cautious with small, new entrepreneurial firms, since lenders have limited information on these firms. From the lender's point of view, transactions with small, new entrepreneurial firms are associated with high probability of agency problems, including moral hazard and adverse selection [13]. There are also evidences that market force cannot correct the problem of capital market imperfection. Kreft and Sobel find that venture capital investment only flew to states with already well-established level of entrepreneurial activity [32]. Therefore, without government intervention, it is unlikely that the states with low entrepreneurial activity will receive enough venture capital investment to support new venture creation.

As new institutional economics argue, rule of law and institution play crucial role shaping entrepreneurial activity. Saravasthy argues that government should function in market-augmenting way rather than market-hindering [29]. Baumol hypothesize that entrepreneurial actions are dependent on economic, legal and institutional [1]. This can be shown in Figure 2. Sobel test Baumol hypothesis empirically and find that institutional quality does increase the level of entrepreneurial activity. This implies that bad institutional quality can be a potential source of market failure. The last argument favoring government intervention is due to externalities [33]. Audretsch argue for three sources of externality that are fundamental source of market failure - network externalities, knowledge externalities, and learning externalities [30]. Network externalities result from "the value of an individual's or firm's capabilities being conditional upon geographic proximity of complementary firms and individuals" Thus, market failures associated with network externalities are likely when there is "a potential for geographic clustering, sectoral linkages, or networks" that can capture local knowledge spillovers. Knowledge externalities are potentials for other firms or individuals to capture knowledge spillovers from a given firm or individual entrepreneur. This is because knowledge, including new ideas, has a public good nature. Even this firm or individual entrepreneur fail, there is still knowledge created. Learning externalities refer to "learning or demonstration effect emanating from entrepreneurial activity" [30]. Audretsch argues that this effect is especially valuable in the areas where entrepreneurship has been largely absent and no strong entrepreneurial tradition is in place.

Given all the sources of market failures discussed above, government intervention seems to be beneficial when properly introduced. We have long heard about different types of public policies, e.g. trade policy, industrial policy, and even innovation policy, which is now quite common public program across all societies. However, in the recent decades, there is the emergence of "entrepreneurship policy". However, like that definition of entrepreneurship that is still not clearly defined, there is a little agreement for what entrepreneurship policy is. Actually, one will find it very difficult to identify the scope of entrepreneurship policy. Besides, we think that Audretsch offers the acceptable description. He defines that entrepreneurship policy is a public program designing to influence the level of entrepreneurial vitality in the society. In addition, Hart argue that entrepreneurship policy encompasses different types and aspects of public programs [34]. Furthermore, these programs are usually uncoordinated. There are other crucial aspects of entrepreneurship policy worthy to address here. 
Citation: Quttainah MA (2015) Entrepreneurship, Innovation and Public Policy: A Survey of Literatures. Int J Econ Manag Sci 4: 279. doi:10.4172/21626359.1000279

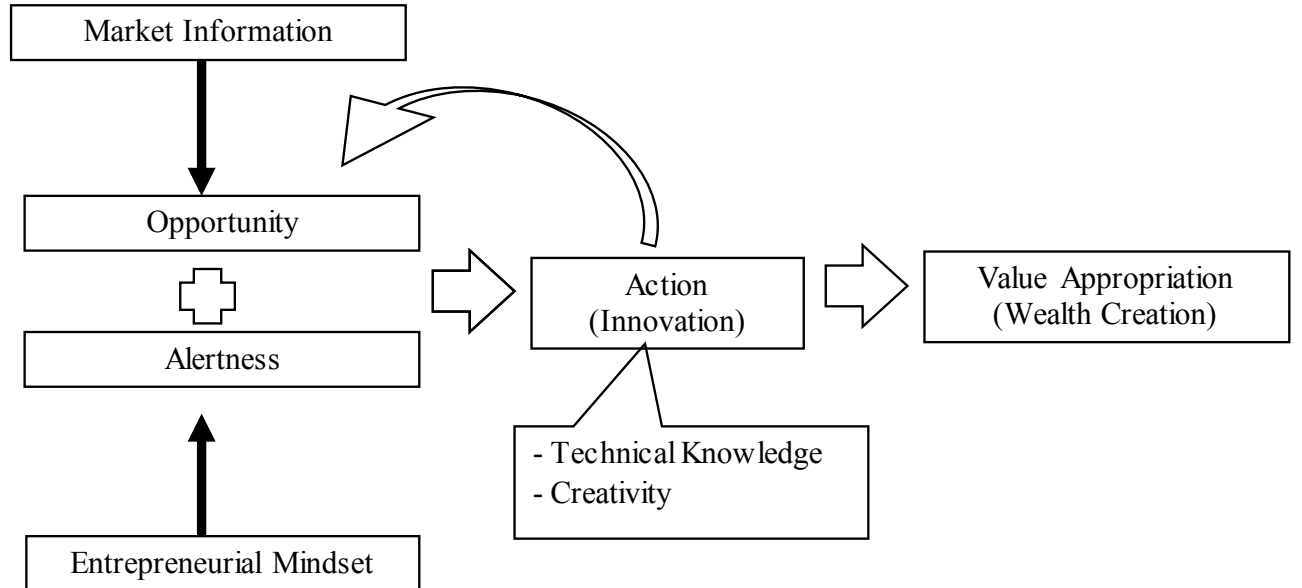

Figure 1: Entrepreneurial Process Developed [27] with some modifications.

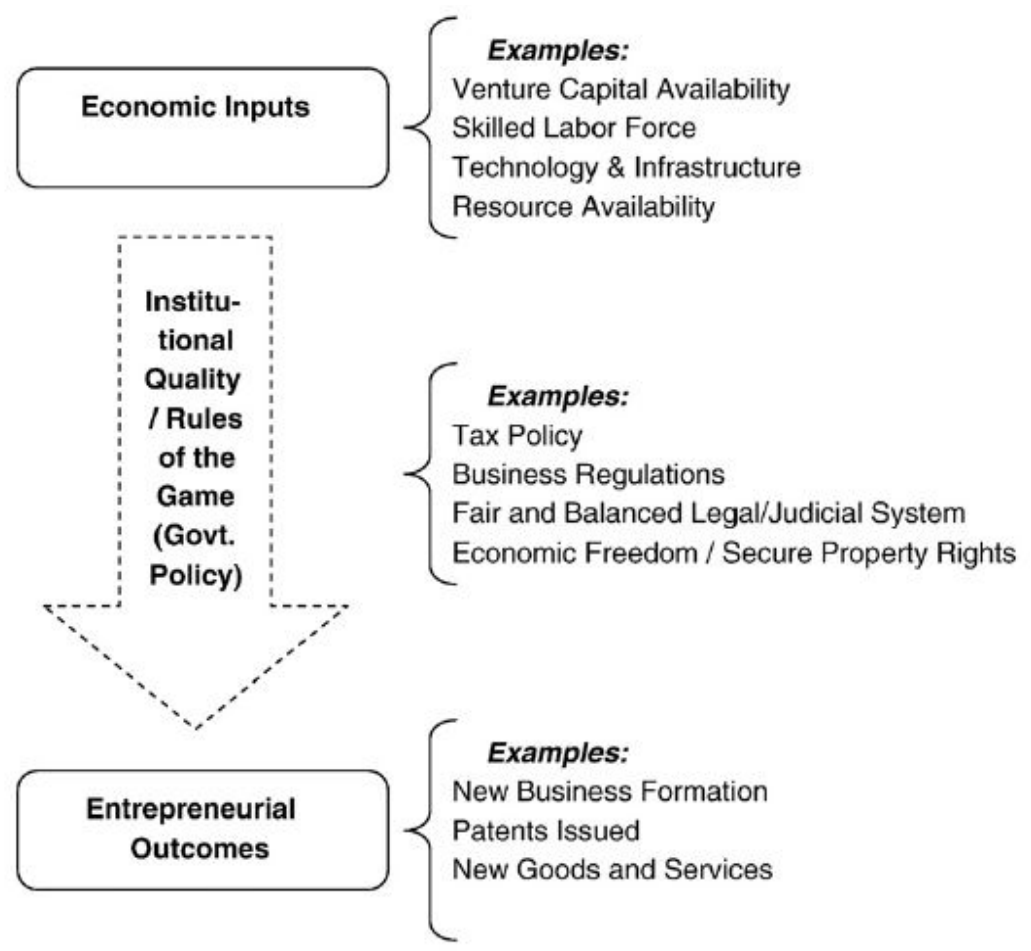

Figure 2: Baumol's entrepreneurial process [33].

a. Entrepreneurship policy is not SME policy. It does not aim at SME survival. Rather, entrepreneurship policy aims at helping potential new entrepreneur as well as existing enterprises.

b. Entrepreneurship policy is not innovation policy, as innovation only aims at enhancing individual or firm's innovative process. Therefore, we would argue that innovation policy is only a subset of entrepreneurship policy.

c. Entrepreneurship policy encompasses multiple units of organization and analysis, from individual, team, firm, industry to national levels.

Acs and Szerb [8] identify entrepreneurial policy to include policies at different policy levels. These include trade policy and immigration policy at the global policy scale, innovation policy, antitrust policy, and property rights regulations at the national policy scale, cluster development program at the regional policy scale, and financial subsidy and tax policy at the entrepreneurial scale. But as [34] Hart these policies are usually uncoordinated. They are found, implemented and evaluated by different government units. Therefore, it may turn out that altogether these policies are barriers to entrepreneurship and innovation.

However, there are recent trends may lead to better coordination for entrepreneurship policies. [23] Audretsch argue that there are shifts in entrepreneurship policy. Firstly, entrepreneurship policy usually emphasize on contracts, e.g. antitrust policy. However, now the policy 
emphasis is on the creation and commercialization of knowledge. It can be observed that entrepreneurship policy at different policy scale include this new emphasis in policy formation process. For instance, trade policy now addresses the issue of commercialization of knowledge and ideas, while cluster development policy focus on stimulating the creation of new knowledge through knowledge spillovers. Secondly, Audretsch argue that there is the downsizing in policy focus. Usually, the policy importance is addressed at federal or state level. However, the new entrepreneurship policy is moving more toward local, firm or even individual levels. There is a growing availability of policy scheme tailored to suit firm and individual differences.

\section{Future Research and Conclusion}

This paper tries to accomplish two tasks. First, we would like to review the recent development of theories of innovation and entrepreneurship. As Baumol argue, it is either incomplete or misleading to consider "innovation" and "entrepreneurship" in isolate. Thus, we review the related literature and argue for the development of integrative framework that combines theory of innovation with theory of entrepreneurship. Second, we address the issue of entrepreneurship policy [35]. Entrepreneurship policy is a relative new terminology. We argue that in the development of entrepreneurship as a field of research, it needs to take into account the issue of the emergence and development of entrepreneurship policy; as such policy may have significant effect on entrepreneurial process.

As our survey of literatures on innovation, entrepreneurship and public policy reveals, it is now crucial that entrepreneurship researchers take into consideration the multidisciplinary/multilevel perspectives. There are few research questions we would like to address here, particularly innovation, entrepreneurship and public policy.

a. How different types of entrepreneurship policy and public regulation affect micro-structure, including firm, group and individual entrepreneur? Do individual differences filter the impact of public policy?

b. Do each type of entrepreneurship policy complement, substitute or confound each another?

c. What are the appropriate matrices that we can use for formulating, implementing and evaluating entrepreneurship policy?

As the field of entrepreneurship is emerging, there are a lot of challenges on theoretical development. Innovation and public policy are issues that have to be considered concurrently with the development of new theory of entrepreneurship in order to explain the unexplained real world phenomenon. Otherwise, new theory is neither more complete nor more useful than the existing one.

\section{References}

1. Porter ME (1985) The competitive advantage: Creating and sustaining superior performance. NY: Free Press London.

2. Mansfield E (1980) Basic research and productivity increase in manufacturing. The American Economic Review 70: 863-873.

3. Baumol, William J (2002) Towards microeconomics of innovation: Growth Engine Hallmark of Market Economy. AEJ 30: 1-12.

4. Romer PM (1986) Increasing returns and long-run growth. The Journal of Political Economy 94: 1002-1037.

5. Romer PM (1990) Endogenous technological change. The Journal of Political Economy 98: 71-102.

6. Lucas RE (1988) On the mechanics of economic development. Journal of Monetary Economics 22: 3-42.

7. Michelacci C (2003) Low returns in R\&D due to the lack of entrepreneurial skills. Economic Journal 113: 207-225.
8. Acs ZJ, Audrestch DB, Braunerhjelm P, Carlsson B (2004) The missing link: The knowledge filter and entrepreneurship in endogenous growth, CEPR Discussion paper 4783, CEPR, London.

9. Shane S, Venkataraman $S(2000)$ The promise of entrepreneurship as a field of research. Acad Manage Revi 25: 217-226.

10. Shah S, Tripas M (2007) The accidental entrepreneurship: The emergent and collective process of user entrepreneruship. Strategic Entrepreneurship Journal 1: 123-140.

11. Solow RM (1957) Technical change and the aggregate production function. Review of Economics and Statistics 39: 312-320.

12. Arrow K (1962) Economic welfare and the allocation of resources for invention In the rate and direction of inventive activity: Economic and social factors. Princeton University Press. National Bureau of Economic Research 609-626.

13. Cohen, Wesley M, Levinthal, Daniel A (1989) Innovation and learning: The two faces of R\&D. The economic journal 99: 569-596.

14. Griliches Z (1979) Issues in assessing the contribution of research and development to productivity growth. Bell Journal of Economics 10: 92-116.

15. Griliches Z (1980) Market value, R\&D, and patents. Economics letters 7: 183-187.

16. Acs, Zoltan J, Audretsch, David B (1990) Innovation and small firms. Mit Press.

17. Schumpeter JA (1934) The theory of economic development: An inquiry into profits, capital, credit, interest, and the business cycle. Transaction Publishers 55.

18. Spencer AS, Bruce AK (2006) Schumpeter and new technology based firms Towards a framework for how NTBFs cause creative destruction. International Entrepreneurship and Management Journal 2: 145-156.

19. Minniti M, Lévesque M (2008) Recent developments in the economics of entrepreneurship. Journal of Business venturing 23: 603-612.

20. Ashraf N, Camerer CF, Loewenstein G (2005) Adam Smith behavioral economist. Journal of Economic Perspectives 19: 131-145.

21. Knight FH (1921) Risk, uncertainty and profit. New York: Hart, Schaffner and Marx.

22. Kahneman D, Tversky A (1974) Subjective probability: A judgment of representativeness. The Concept of Probability in Psychological Experiments $25-48$.

23. Audretsch DB (2002) Entrepreneuship A Survey of Literature.

24. Kirzner IM (1973) Competition and Entrepreneurship. Chicago, 111: University of Chicago Press.

25. Christensen TJ, Snyder J (1997) Progressive research on degenerate alliances. American Political Science Review 91: 919-922.

26. Schumpeter JA (1939) Business cycles. New York: McGraw-Hill. 1: 161-74.

27. Burgelman RA, Hitt MA (2007) Entrepreneurial actions, innovation, and appropriability. Strategic Entrepreneurship Journal 1: 349-352.

28. Nelson RL (1959) Merger movements in American industry, NBER Books 1895-1956.

29. Sarasvathy SD (2004) The questions we ask and the questions we care about: reformulating some problems in entrepreneurship research. Journal of Business Venturing 19: 707-717.

30. Audretsch DB (2004) Sustaining innovation and growth: Public Policy Support for Entrepreneurship. Ind Innovation 11: 167-194.

31. Ketchen J, Ireland RD, Snow CC (2007) Strategic entrepreneurship collaborative innovation, and wealth creation. Strategic Entrepreneurship Journal 1: 371-385.

32. Kreft SF, Sobel RS (2005) Public policy, entrepreneurship, and economic freedom. Cato J 25: 595-616.

33. Sobel RS (2008) Testing baumol: Institutional quality and the productivity of entrepreneurship. Journal of Business Venturing 23: 641-655

34. Hart O (2003) Incomplete contracts and public ownership: Remarks and an application to public-private partnerships. The Economic Journal 113: C69-C76.

35. Koppl R (2006) Austrian economics at the cutting edge. Review of Austrian Economics 19: 231-241. 